\title{
"What's under There?" The Questioning of Civil Rights for Sikh Men
}

\author{
Muninder K. Ahluwalia \\ Montclair State University
}

\begin{abstract}
On the heels of the highly publicized deaths of multiple Black youth in the U.S., the case of Trayvon Martin is yet another tragedy. While we mourn his loss, his death should also be seen as a call for justice for him, and more broadly a call for social justice. In this manuscript, parallels between the Black and Sikh communities in the U.S. are highlighted. In particular, the suspension of rights of and violence against Sikh men and boys in the U.S. and globally are identified along with examples of social justice action taken by Sikh organizations and mental health professionals in response to acts of oppression. This article represents a call to action for all communities to engage in support of social justice across groups.
\end{abstract}

Keywords. Sikh, Black, men, civil rights, discrimination

\section{Introduction}

What is it about a head covering that makes people nervous? Or more specifically, what feels so threatening to others when people of color cover their heads? What do people think is under there?

These questions highlight a fundamental distrust between communities wherein covering one's head in the U.S. seems to be equated with hiding ones' true identity. In reality, the head covering may more accurately be a reflection of cultural and/or religious community. The fear and anger that has characterized the U.S. society's response to cultural communities who distinguish themselves through specific forms of dress (e.g., a hoodie, turban) contributes to 
the perception that these minorities are somehow "flaunting" their differences by not conforming to mainstream norms and therefore, do not belong. In reality, wearing a cultural indicator of membership to a particular community (e.g., a religious symbol) holds meaning for these communities that may not be shared or understood by others. Interestingly, for many communities of color, even if members were stripped of dress that indicates their cultural membership, many would still not fit in to mainstream norms because of other physical indicators (e.g., skin color).

There was some realization that the U.S.'s political, ideological, and economic policies have bred hatred when terrorism hit American soil on September 11, 2001 (hereafter referred to as 9/11). Over a decade later, the U.S. continues to struggle both internationally as well as domestically with issues of racism, discrimination, stereotyping, and hate crimes that have resulted in the erosion of humanity and loss of life. This year alone, 2012, was plagued with reports of multiple shootings of young Black men, acts of anti-Semitism, Islamaphobia, and homophobia. Horrific acts of destruction occurred in homes and community spaces that should be considered safe. What remains even more problematic is that some of the perpetrators are those whose role it has been to protect members of American society. For example, police officers and members of neighborhood watch programs perpetrated shootings in the Black community. The murder of Trayvon Martin, a Black high school student who was walking near his home when a neighbor shot and killed him, was publicized widely in the media. He was 17 years old and had committed no crime, save being young, Black and male wearing a hoodie. The U.S. must mourn the loss of this youth for who he was and who he was yet to be in his family, school, community and to the country. This manuscript focuses on the author's reflections of the Trayvon Martin murder and other acts of violence against the Black community drawing parallels with acts of violence against the Sikh community.

I have been reflecting on the similarities and differences about these murdered boys and men in the Black community, and the Sikh boys and men in my own life. As a Sikh woman, I have a father, brothers and nephews. The situation facing Sikh men and boys in the U.S and abroad parallels the experiences of Black males, like Trayvon Martin in many ways. Issues of profiling, loss of civil rights and violence targeted towards men and boys are issues that both the Black community and the Sikh community continue to experience. I present my thoughts with one caveat; that is, I am also wary of drawing parallels between the African American experience and the Sikh experience because although the sociopolitical histories of the two groups in the U.S. are intertwined (e.g., legacies of denial of citizenship, land ownership), they are also very different (e.g., forced migration and enslavement vs. immigration for opportunity). Further, I recognize that the myth of Asian Americans as the model minority, which systematically pits Asian Americans against other minority groups (including African Americans) while maintaining the White norm as ideal, has benefitted members of the Indian American Sikh communities. Yet, Sikh American boys and men are seen as strange and even dangerous (Ahluwalia, 2010; Joshi, 2006); outsiders in their own country and public enemies in the U.S.

In this manuscript, I reflect on the treatment of Sikh men and boys in the U.S. and globally. In particular, I discuss the suspension of rights of Sikh men who have unshorn hair and are readily identified with jooras (topknot), hankies (that cover the joora), patkas (a bandana-like headcovering that covers not only the joora but all the hair), and turbans. I focus on Sikh men in particular given the readily evident visible identifiers of our religion. Sikh women also have uncut hair and may also cover their heads with a chuni (scarf) or a turban, but it is done much 
less frequently outside gurdwara (Sikh place of worship) and does not seem to have the same implications as it does for men. Sikh men are routinely mistakenly identified in acts of racial profiling as "terrorists." There have been numerous documented cases of stereotyping, profiling, loss of human and civil rights, and hate crimes (Ahluwalia \& Pellettiere, 2010).

\section{Sikhism, Context and "The Other"}

An understanding of the historical, political, economic and social context is imperative in understanding the experiences of men and boys in the Sikh community. Sikhism is the fifth largest religion in the world and yet, few people know who Sikhs are, what they believe and the principles for which they stand. The Sikh Gurus leave practitioners of the religion with a legacy of social justice. Sikhism was formed in a time when there was Islamic rule of the majority Hindu country of India. Under particular Mughal emperors, there were differences in how Hindus were treated. Some were tolerant of religious differences between themselves as rulers and their constituencies, whereas others excised additional taxes from non-Muslims and even forced conversions. It is in this climate of oppression that Sikhism was born and solidified. The ideal for a Sikh is to aspire to be a saint-soldier - to pray and meditate, but also be willing to fight against injustice. Sikhs fought against oppression of Hindus by Muslims, of lower caste by upper caste Hindus, and of women by men.

Mainstream media in the U.S. is the major source of information regarding the Sikh community and it is derived by comparison with the White American Christian majority. Media images of men with turbans as terrorists prevail (Ahluwalia \& Pellettiere, 2010). By default, many people assume Sikhs are terrorists, potential terrorists, or sometimes, Muslim. The irony of course is that the only group of individuals who wear turbans in the US are Sikhs, while the media images are only of turban-wearing Muslims in other countries. In fact, shortly after $9 / 11$ and even recently, governmental and news sources have mistakenly identified Sikhs as Muslims, who are misidentified as terrorists. It is important to emphasize that I am not using Muslim and terrorist synonymously and that I am extremely cognizant that Muslims repeatedly get targeted for looking like, sounding like, identifying with the same religion as terrorists (Ahluwalia \& Zaman, 2009). This situation is heinous as misrepresentations and stereotyped profiling mark a lack of community understanding, misidentification, and ignorance (i.e., overgeneralizing from a few to the many).

Like Black Americans, Sikhs have experienced a serious backlash that continues well beyond September 11, 2001, and in fact, began long before 9/11. Sikh men have been targets of racial slurs, beat up, and even killed because they "look like" the enemy in the U.S.'s "war on terrorism". Their right to practice their religion has been systemically eroded globally (e.g., France), and there has been no justice for Sikh victims of torture and killings in India.

The calls for justice in response to the $9 / 11$ back lash against the Sikh community have gone unanswered, in part because Sikhs comprise such a small percentage of the U.S. population. Yet, to allow these acts to continue is to erode our moral imperative to stand for humanity and freedom for all, regardless of the size of the community in the U.S. For psychologists and counselors, it is an ethical imperative to advocate and fight for social justice for marginalized groups. It was not so long ago that much of the psychological research was based upon mainstream, White American males. Representation of various minority groups was considered irrelevant. We can see now how problematic this is. 
Who is identified as the "other" in the U.S. mainstream discourse is not based upon length of time in the country's history. Sikhs have been in the U.S. since the late 1800s and yet, they have been, and continue to be, the "other," as are Black youth (such as in the case of Trayvon). Injustice must be addressed in all communities so that the desire to define and target the "other" can be reframed to an embracing of diversity across groups. This is a complex issue given that discrimination and -isms (e.g., racism, sexism, classism) are integrated into all societal systems and individuals are socialized with these -isms. To end oppression means that we must impact systems, individuals, and communities socially identified as mainstream. Further, members of the dominant group will have to give up privilege. This is a difficult task given that people are often not aware of the unearned privileges that they possess. Privilege is often invisible and there exists a societal rhetoric to justify why those who hold privilege deserve what has been bestowed upon them.

\section{Illustrative Cases of Oppression}

Reflecting the above theme of fear in the majority resulting in violation of civil rights of ethnic and religious minorities, there are a number of recent cases illustrating this violation of Black boys and men's civil rights, as well as those of Sikh boys and men. The cases of disregard for Sikh boy's and men's rights focus on events occurring on personal, individual, U.S. community, and at international levels in France and India. The erosion of rights leads to the creation of second-class citizens who are not entitled to the same rights as those from the dominant group. While some cases point to the indictment of individual perpetrators, there nevertheless exists a lack of attention to earlier acts of discrimination and oppression.

\section{A Boy is Profiled at U.S. Airport}

A young boy, age 9, was pulled aside and double screened at a U.S. airport. His hands were swabbed and tested for explosives (see Ahluwalia, 2011), as if testing the hands of children would make this country safer. Throughout his short lifetime, he has consistently seen his father pulled aside and double screened in a variety of ways. The father wears a turban and the boy wears a patka. This is my nephew and this was only the beginning of a life of routine airport profiling.

\section{A Terror Attack on Oak Creek Gurdwara}

On August 5, 2012, six members of the Sikh Gurdwara in Oak Creek, Wisconsin, were shot and killed. "The shooting occurred between the end of the Sikh religious service and the beginning of langar (which means 'community kitchen' and is a Sikh tradition to prepare and offer food to the congregation and anyone who is in need), a sacred time of community connection and devotion" (Singh \& Ahluwalia, 2012, para. 2). There were five men and one woman killed, all wearing head coverings (turbans and a chuni, respectively). Attorney General Eric Holder called the shooting an "act of terrorism, an act of hatred, a hate crime" (CNN Wire Staff, 2012). The terrorist was a white supremacist who, after being shot by police, killed himself. 


\section{France Bans Religious Identifiers in Public Institutions}

In 2004, France passed a law banning religious symbols in public schools, including Sikh turbans and Muslim headscarves. In the years following the passage of the law, individuals renewing passports and certain official documents have also been asked to remove the religious headgear for photographs (Neiyyar, 2012). An example of this is Ranjit Singh, who was forced to remove his turban for his driver's license identification card in France. The impetus of the law originated in xenophobic, more specifically Islamaphobic, alarm in response to non-Christian religious symbolic apparel (e.g., hijab) worn by individuals protesting quite vocally at their treatment and status in France. Though all religious symbols in dress are banned from schools and government institutions, Sikh, Muslim and Jewish individuals are most impacted. No Sikh child wearing a patka or turban, no Muslim child wearing a hijab, and no Jewish child who wears a yarmulke can attend public school in France. When Sikh boys were told they could no longer attend public school in France, their parents were left with three options: private school (if they had the funds), give up their religion and corresponding visible markers, or move out of the country (if they were mobile).

\section{Sikhs Killed in 1984 Genocide in India}

In 1984, Sikh separatists had taken refuge in the Golden Temple, the most sacred site and place of worship for Sikhs. Under Prime Minister Indira Gandhi, the Indian Army attacked the Golden Temple. Innocent Sikhs were killed, historical documents destroyed, and historical buildings were severely damaged. In retaliation, the Prime Minister's two Sikh bodyguards killed her. In response to the assassination, at least 4,000 Sikhs were murdered over the course of three or four days (Amnesty International, April 9, 2009; Hardgrave, 1985). Almost 30 years later, the Indian government still has not brought the perpetrators to justice (i.e., those responsible for the Anti-Sikh programs). In fact, there was clearly a "systematic and organized manner in which state institutions and Congress officials perpetrated mass murder in November 1984 and later justified the violence in inquiry proceedings" (Ensaaf, n.d.b.). Ensaaf explains that since 1984, there has been continued torture and disappearances of Sikh men and boys, with little to no justice for victims and families of victims in India.

\section{Action}

Systemic oppression must be acknowledged and ended. Conversations within and across communities must happen with a focus on action. I am going to highlight some actions that have been taken in response to individual and systemic oppression against Sikhs and discuss a number of ways Sikh community organizations have worked to combat injustice. I will also briefly outline one way I have integrated social justice into the training of counselors. My goal is to help the reader consider some ways individuals and groups have engaged in social action in the face of the erosion of civil and human rights.

\section{Seva in the Aftermath of Oak Creek}

On August 5, 2012, on the last day of the American Psychological Association Convention, I received a flood of text messages from friends and colleagues about a shooting at the Oak Creek Gurdwara. Although the media response was swift and 
educational, the coverage ended within days. The man who inspired the terror had killed himself after being shot by a police officer. For the mainstream media, the story was over. For the Sikh community the story was just beginning.

Sikhs who were trained as mental health practitioners came together to provide psychoeducation and mental health services to the Sikh community in Oak Creek and nationally, while simultaneously educating mental health organizations to better serve this community. These practitioners were joined by other South Asians, and professionals from other racial, ethnic, and religious groups who felt a pull to do something in the face of this tragedy.

I knew that after being paralyzed into inaction after $9 / 11$, this time had to be different for me. I immediately contacted Anneliese Singh, a fellow Sikh counseling psychologist and counselor educator. We were in agreement that we had to do seva (community service), beginning with a very brief public statement about Sikhs, useful websites, and references for further education (see Ahluwalia \& Singh, 2012). We sent it to counseling and psychological professional associations, list-serves, and other sources. The two of us continue to work together and with many others to continue to provide psychoeducation to members of the Sikh community as well as provide information about the Sikh community to mental health practitioners.

\section{Mobile Application to Document Airport Profiling}

In response to airport profiling, community organizations, such as the United Sikhs and Sikh Coalition, have tried to document cases to help advocate for policy changes. Although individuals from multiple communities (e.g., Muslim, Sikh) have experienced profiling, there has been no easy and accessible way for people to report incidences. As a result, airport profiling has been grossly underreported and systematically dismissed as a reality. In response to this need for an easier report mechanism, the Sikh Coalition created Flyrights mobile application that allows users to report airport profiling instances in real time (Sikh Coalition, n.d.). This documentation of individuals' experiences from diverse (not only Sikhs) backgrounds is important as they "will be considered actionable complaints by the Transportation Security Administration (TSA) and the Department of Homeland Security (DHS)" (Sikh Coalition). What makes this notable is that a community organization that fights for Sikhs' rights, created a systemic change that benefitted Sikhs and non-Sikhs facing discriminatory profiling.

\section{Taking France's Violation of Human Rights to the United Nations}

In response to the forced removal of Sikhs' religious symbols in public institutions in France, the issue was taken to the United Nations. In particular, Ranjit Singh and United Sikhs, a Sikh advocacy organization, presented the issue to the United Nations Human Rights Commission (UNHRC), which "held that France had violated the religious freedom of a Sikh by asking him to remove his turban for an ID photograph" (United Sikhs, n.d.). France has responded that they belong to the European Union and are responsible to them, not the United Nations. Though France continues to uphold laws and policies that are oppressive, it has been important to the Sikh community that a body such as the United Nations acknowledged the violation of rights of Sikhs. 


\section{Seeking Justice from the Indian Government}

In 2004, Ensaaf (justice), an organization dedicated to promoting human rights, justice and accountability in India, was created. Specifically, Ensaaf was formed with a commitment to achieving justice for mass state crimes in India. They work on community organizing and education, documentation of the crimes, legal advocacy, and advocacy with the United Nations (Ensaaf, n.d.a.). Specifically, their focus is on the state of Punjab and the impunity situation, disappearances, and unlawful killings of Sikhs. The team systematically works in the U.S. and India to legitimize the issue and build cases on behalf of the victims of the programs.

\section{A Small impact: Our Diversity Course}

I regularly teach the diversity course (i.e., Multicultural Counseling and Development) in a counseling graduate program and though we address knowledge, awareness and skills, each semester, students were left feeling, "what next?" They often did not have the practical skills necessary to put their newfound awareness and knowledge of disparities, oppression and other injustices into action. Students sometimes left feeling helpless and their awareness would erode over time, worn away by systems that did not want them to make the shift in their perspectives. To address this, I now use class time in the multicultural counseling class throughout the semester to consider advocacy, alongside their learning of individual counseling skills. As one of their culminating activities, they outline what their action will be after they complete the class (and sometimes it is just a baby step). Through this activity, students develop a plan and are empowered to take action. Students have had varied action plans, including working with religious communities on issues that of importance to those communities, organizing efforts to inform legislators of issues facing racial and ethnic minority communities, and providing knowledge about marginalized groups in local venues (e.g., public library).

In addition, in the multicultural counseling course, my colleague, Amanda Baden (who also regularly teaches the course) and I collaborated to include attention to Sikhs, in addition to other religious minorities (Ahluwalia, 2011). This became a systemic change in that all of our students are exposed to communities that most had never heard about, never noticed, or have negatively stereotyped. These two small actions have helped to inform students about particular issues by minority religious communities in the U.S. and abroad, as well as to consider how they can advocate and fight for social justice on a broader level for all groups.

\section{Conclusion}

In reading the cases described above, are you moved to action? What could you do about oppression that you have read about and that you witness? I ask you to consider whether you can recall instances from your own history and experience like the ones described earlier in this article. In your process of reflection; note similarities and differences in identities between you and the subjects of these cases. Pay attention to your own privilege (and oppression) related to the identities in these stories. Could you ever be in a situation where your rights are eroded and you experience oppression? Would you march in protest for your rights? Would you march for 
others? What about a young African American man? A Muslim woman? A young Sikh boy? Would you march in the "hoodies and hijab" rally (Flock, 2012)? Would you march in a rally on behalf of those who wear patkas and turbans? Alternately, would you participate in a candlelight vigil, as so many did in the U.S. after the Oak Creek shootings?

Social justice advocacy for the Sikh community has to be ongoing and needs to be addressed in clinical work, training, research, and policy levels. Working to educate larger society, training future professionals to be multiculturally competent, studying communities' challenges and strengths, and advocating for legislation that provides justice (e.g., tracking hate crimes) is as important as providing therapeutic interventions. Psychologists, counselors, and other mental health professionals have to see advocacy and fighting for social justice as equally important as the individual work they do.

The above questions lead me to ask, where does your stake end and others' begin? This is my call to action. I hope this is your call to action as well. The loss of Trayvon Martin's human rights, and his life, is a loss of humanity. We need to seek justice for him...and we need to seek justice for all.

Author Note: The author wishes to thank Drs. Lisa Suzuki and Rebecca Toporek for their invaluable feedback on this manuscript.

\section{Contact information:}

Dr. Muninder K. Ahluwalia

Montclair State University

Email: Ahluwaliam@mail.montclair.edu

\section{References}

Ahluwalia, M. K. \& Singh, A. A. (2012, August 6). Letter on Oak Creek. Retrieved from http://www.northwestern.edu/studentaffairs/student-affairsupdates/sikh_gurdwara.html

Ahluwalia, M. K. (2011). Holding my breath: The experience of being Sikh after 9/11. Traumatology, 17(3), 41-46.

Ahluwalia, M. K. \& Pellettiere, L. A. (2010). Sikh men post-9/11: Misidentification, discrimination, and coping. Asian American Journal of Psychology, 1(4), 303-314. 
Ahluwalia, M. K. \& Zaman, N. (2009). Counseling Muslims and Sikhs in a post-9/11 world. In

J. G. Ponterotto, M. Casas, L. A. Suzuki, \& C. Alexander (Eds.), Handbook of multicultural counseling (3rd ed., pp. 467-478). Thousand Oaks, CA: SAGE.

Amnesty International (2009, April 9). Sikh massacre victims await justice in India, 25 years on. Retrieved from http://www.amnesty.org/en/news-and-updates/sikh-massacre-victimsawait-justice-india-25-years-20090409

Bhatia, R. K. (2012, January 21). French Sikh wins turban case against France in UN. Retrieved from http://www.unitedsikhs.org/US_News/US_News_21012012.php

CNN Wire Staff. (2012, August 10). At service, Holder calls Sikh temple shooting a hate crime. CNN U.S. Retrieved from http://articles.cnn.com/2012-08-10/us/us_wisconsin-templeshooting_1_sikh-temple-turbans-oak-creek-high-school

Ensaaf (n.d.a.). Ensaaf: A mission to end impunity. Retrieved from www.ensaaf.org

Ensaaf (n.d.b.). Documentation: 1984 Pograms of Sikhs. Retrieved from http://www.ensaaf.org/programs/documentation/

Flock, E. (2012, March 27). Trayvon Martin case, Iraqi woman's death spark 'hoodies and hijab' rally. Washington Post Blogpost. Retrieved from http://www.washingtonpost.com/blogs/blogpost/post/trayvon-martin-case-iraqiwomans-death-spark-hoodies-and-hijab-rally/2012/03/27/gIQAI6IieS_blog.html

Hardgrave Jr., R. L. (1985). India in 1984: Confrontation, assassination, and succession. Asian Survey, 25(2), 131-144.

Joshi, K. Y. (2006). The racialization of Hinduism, Islam, and Sikhism in the United States. Equity and Excellence in Education, 39, 211-226.

Neiyyar, D. (2012, January 13). UN human rights body backs French Sikhs on turbans. $B B C$ News Europe. Retrieved from http://www.bbc.co.uk/news/world-europe-16547479

Sikh Coalition (n.d.) Sikh Coalition, retrieved from www.sikhcoalition.org

Singh, A. A., \& Ahluwalia, M. K. (2012, August 16). Sikh counselor educators offer perspective on Oak Creek shooting. Counseling Today. Retrieved from http://ct.counseling.org/2012/08/sikh-counselor-educators-offer-perspective-on-oakcreek-shooting/ 